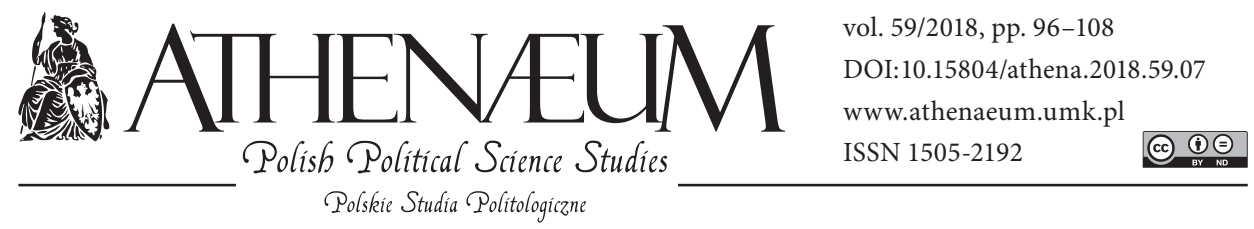

\title{
DIGITAL GOVERNMENT - REAL CHANCES FOR POLAND OR MERE FANTASY?
}

\author{
CYFROWE PAŃSTWO - \\ REALNE SZANSE DLA POLSKI CZY MRZONKI?
}

Beata Stachowiak*

\begin{abstract}
Digital government became synonymous with modern, innovative state structures in which information and communications technologies play a key role - both in the realm of public and commercial services. However, the process of digitization is not free of disturbances. Oftentimes, the source of the latter is the so-called human factor. That is why, what is vital is the social research diagnosing how e-services are received, with the research assessing the level of knowledge on the dangers connected therewith or else, describing the expectations towards the services provided online. Neglecting such research usually leads up to the misallocation of public resources. This paper presents the results of the research conducted among the inhabitants of Kuyavian-Pomeranian Voivodeship, with the research testing their attitudes towards public e-services.
\end{abstract}

Keywords: digital government, Poland, e-administration, citizen, information society
ABSTRAKT

Cyfrowe państwo stało się synonimem nowoczesnych, innowacyjnych struktur państwowych, w których technologie informacyjno-komunikacyjne odgrywają kluczową rolę zarówno w obszarze usług publicznych, jak i komercyjnych. Jednak proces cyfryzacji nie przebiega bez zakłóceń, często ich źródłem jest tzw. czynnik ludzki. Dlatego tak ważne są badania społeczne diagnozujące odbiór e-usług przez społeczeństwo, oceniające poziom wiedzy na temat zagrożeń czy też opisujące oczekiwania wobec usług świadczonych online. Zaniechanie takich badań zazwyczaj prowadzi do niewłaściwego wykorzystywania środków publicznych. W artykule zostały przedstawione wyniki badań przeprowadzonych wśród mieszkańców województwa kujawsko-pomorskiego w zakresie ich stosunku do publicznych e-usług.

Słowa kluczowe: państwo cyfrowe, Polska, e-administracja, obywatel, społeczeństwo informacyjne

* Nicolaus Copernicus University in Toruń, Faculty of Political Sciences and International Studies. ORCID: https://orcid.org/0000-0003-1805-3306. 


\section{INTRODUCTION}

The present paper constitutes an attempt to answer the following questions: Are Polish citizens (and if so, then to what extent) ready for the digital government? In 2016, the report Cyfrowa Polska. Szansa na technologiczny skok do globalnej pierwszej ligi [Digital Poland: Capturing the Opportunity to Join Leading Global Economies] was published, with the attributive adjective "digital" being key therein. In the said document, what was subject to scrutiny was the digital potential of Poland as well as the level of digitization of the selected sectors (Boniecki et al., 2016). This publication is a continuation of the reports dating back to 2015 and bearing the titles: Polska 2025. Nowy motor wzrostu [Poland 2025: New Economic Driving Force] and 5 zadań dla Polski [5 Tasks for Poland]. The theses included in the publication dating back to 2016 constitute a creative development, done by the employees of McKinsey \& Company and of the monthly "Forbes", of the contentions being present in the report by Martin Bangemann from 1994, which initiated the building of information society in the European Union (Bangemann, 1997). Succinctly speaking, these might be put in the following way: the societies that do not embark on timely opportunities to digitize themselves will not be able to catch up on civilizational backlog. What is more, the lack of development will be tantamount to regress. The postulates expressed in the said report are undoubtedly justified; yet, in its author's opinion, a significant part of the report is produced from the point of view of the inhabitants of large cities, of educated people as well as the ones whose income is above the national average.

Also, all sorts of strategies and policy papers do not take into consideration the so-called local conditions, that is, the provinces broadly understood. The all-Polish research Diagnoza Społeczna [Social Diagnosis] indicates that the variation in the use of the Internet between the inhabitants of major cities and the ones of the countryside amounts to as much as $25 \%$ percentage points. The income is also a statistically significant factor, albeit less important than age or education (Batorski, 2015). And still, the data from the recent population count in Poland, dating back to 2011, indicates significant differences with respect to the education acquired among major cities and the countryside. When it comes to cities, there is as much as $21.4 \%$ of the population that possesses higher education, whereas in the countryside - as little as 9.8\% (Główny Urząd Statystyczny, 2012). It is also income that is not distributed evenly across all sorts of areas of Poland. If we are to assume that the average income in 2016 for Poland is 
100 , this value reached the level of as much as 133.8 for the metropolitan area of Poland (centered around Warsaw, our capital city). Furthermore, it reached the value of 122.1 for Masovian Voivodeship, 92.1 for Bydgoszcz, and 85.6 for Kuyavian-Pomeranian Voivodeship (Główny Urząd Statystyczny, 2018). The discrepancies are large and should be taken heed of while coming up with all sorts of strategies and reports.

\section{FOUNDATIONS OF AND THE CHALLENGES FOR DIGITAL POLAND}

The foundations of the digital government according to the Centre for Studies on Digital Government are: the flow of information without barriers, which is pursuant to the act on computerization of business entities pursuing public tasks, which in turn speaks of interoperationality and compatibility of the systems ensuring the flow of data. The next point is to place a citizen at the center of one's attention, which is construed of as providing electronic services to the citizens in an innovative fashion, which is meant to give them tangible benefits in a user-friendly manner. The third crutch is openness and participation conceived of as transparency in taking public decisions and as the possibility of citizens' cooperating in that very process. The last but not least pillar is the right to privacy. This task is difficult to pursue because digital government is going to be endowed with much data about citizens, with the data coming from all sorts of records and registers. And when combined, this data will sort of multiply itself. Therefore, the right to privacy will be inextricably intertwined with data safety.

1994 was a symptomatic year not only to the European Union but also to Poland. In December of that year, there took place the proceedings of the First Congress of Polish Information Technology. During that event, what was evaluated for the first time was the state of Polish information technology as well as the perspectives for the development thereof in the context of the building of the information society. Since that moment, in Poland one has been developing the information society, e-Poland projects have been pursued only to put into effect the vision of digital government nowadays (Ministerstwo Łączności, 2001; Komitet Badań Naukowych, 2000; Ministerstwo Nauki i Informatyzacji, 2004). It does not happen without difficulties or problems. The challenges Poland faces are - among others - the low level of interoperationality and the unsatisfactory condition of the flow of data between institutions. The next problem reduces to not paying attention to the citizens' needs, not being aware of what they need 
when it comes to digital services. The central institutions do not evaluate the implemented solutions from the angle of their respective serviceability towards their users. This is evidenced by - among others - the fact of heading for unverified solutions. Najwyższa Izba Kontroli (NIK) [The Supreme Audit Office] in April 2016 published the report on the services of public administration, from which it followed that a little more than $1 \%$ of adult citizens of Poland had a trusted ePUAP profile ${ }^{1}$. Having such a profile is one thing but making use of it is another. They do not necessarily go hand in hand. At this point, it is worthwhile to mention that in the period 2008-2015 PLN 108.5 million were spent on the project ePUAP and successive PLN 123 million is scheduled to be spent in the period 2015-2020 (Naczelna Izba Kontroli, 2016). What also constitutes a danger is digital inabilities on the part of the inhabitants of Poland, which in turn has an indirect bearing on their needs within the remit of digitization. According to the data of Eurostat, the indicator of Polish people openly declaring their digital abilities to be at the basic or above-basic level reaches $44 \%$, with the European Union average being 56\%. What also constitutes a threat to digital government is cyber crimes. It is in this context that we may experience the threat to data safety, to the privacy of citizens and eventually, to the efficient functioning of the state itself.

\section{THE SELECTED INDICATORS OF DIGITIZATION}

For the purpose of this paper, the author thereof will conceive of the readiness for digitizing Poland on three planes. The first of them is making use of Biuletyn Informacji Publicznej (hereinafter referred to as BIP) [Public Information Bulletin]. At the moment of this particular analysis, in 2016, BIP had been already operating for 15 years since its origins date back to 2001, when the law on access to public information was enacted, in which in article 8 , what was brought into effect was an official ICT publication system. The second plane is constituted by ePUAP. The genesis of this solution dates back to 2008. This platform was meant to provide the alternative to an electronic signature, with the latter solution not being particularly popular in Poland. The third plane is e-declarations. This system was launched 1 January 2008 and therefore it had been operating

\footnotetext{
1 ePUAP - Elektroniczna Platforma Usług Administracji Publicznej [Electronic Platform of Public Administration Services].
} 
for 8 years at the moment the research was conducted. E-declarations allow for submitting tax declarations through the Internet. This system quickly became popular not only among institutional users but also among citizens.

Figure 1 represents the number of submitted Pit-37 declarations in the period 2008-2016. After 8 years of the system having been operating, the number of submitted Pit-37 declarations exceeded 6 million.

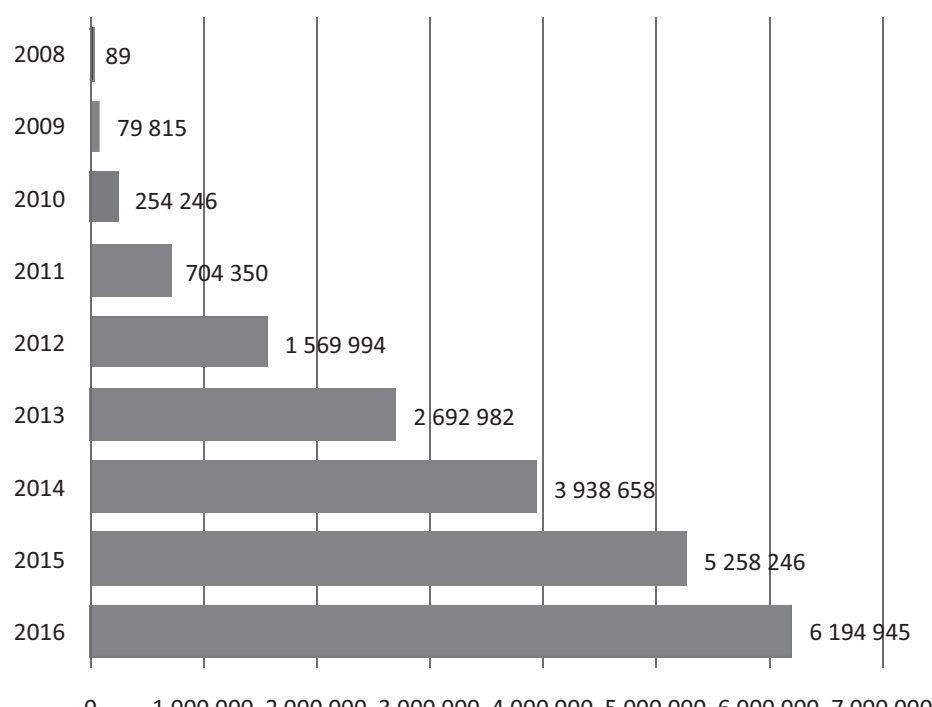

Figure 1. The number of submitted Pit-37 declarations in the period 2008-2016

Source: Ministry of Finance (2018). Retrieved from: https://www.finanse.

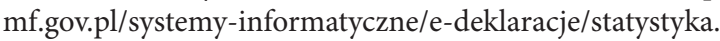

\section{THE METHODOLOGY AND DESCRIPTION OF MY OWN RESEARCH}

The research conducted in 2016 was aimed at diagnosing to what extent the inhabitants of Kuyavian-Pomeranian Voivodeship make use of public services provided electronically. And if they do not do so, for what reasons then? Which factors contribute to making use of public e-services. The choice of the sample was non-random. Rather, it was a convenience sample. The method employed herein was a survey; and strictly speaking, a questionnaire. The questionnaire contained six complex questions and respondent's particulars. The obtained 
results were subject to statistical analysis - among others - the test of chi-square was applied. 2311 surveys were collected, out of which 2101 qualified to be processed further. Some of them were rejected for formal reasons. The respondents were inhabitants of Kuyavian-Pomeranian Voivodeship; $51.8 \%$ of this group was comprised of women, whereas $48.2 \%$ by men. The average age of the respondents amounted to 34 years and the median -28 years. The coefficient of variation - amounting to $44.56 \%$ - proved that the population under scrutiny was diversified in a statistically significant way with respect to age. It was occupationally active people that dominated in this population. This group amounted to $57.3 \%$, persons in education - overall $39.2 \%$, while occupationally inactive persons and persons not in education constituted $17.6 \%$. The detailed illustration of the surveyed persons is presented in Figure 2.

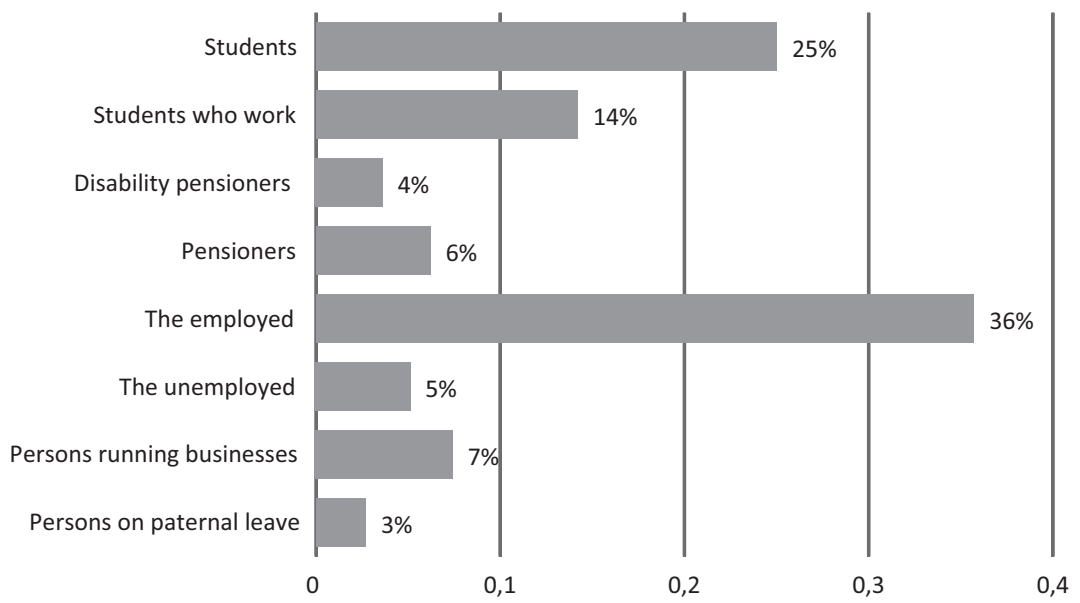

Figure 2. The distribution of the respondents according to their respective occupational status

Source: own research.

The respondents were also asked to assess their respective skills. Having skipped the persons who did not specify the level of their skills, the mean amounted to 3.6, thus yielding a sufficiently good result. Gender did not exert any influence on the assessment of their own skills (chi-square value $=22.751$ with the critical value $=31.41$ and alpha level $=0.05$ ). Some differences were connected with the age of the respondents, which was expected; however, this fact required the division into age groups: 20 -year-olds, 30 -year-olds, etc. The 
key issue was the respondents' attitude to e-administration. As much as $20.3 \%$ of them declared that they are not aware of what e-administration is or, alternatively, they have never come across such a service. It is worth noticing at this point that only as little as $6.8 \%$ of the respondents stated that they do not use the Internet. $34.6 \%$ admitted that they realize what e-administration is but do not avail themselves of such services. A little more than $10 \%$ maintained that they regularly or often make use of it. The details are presented in Figure 3.

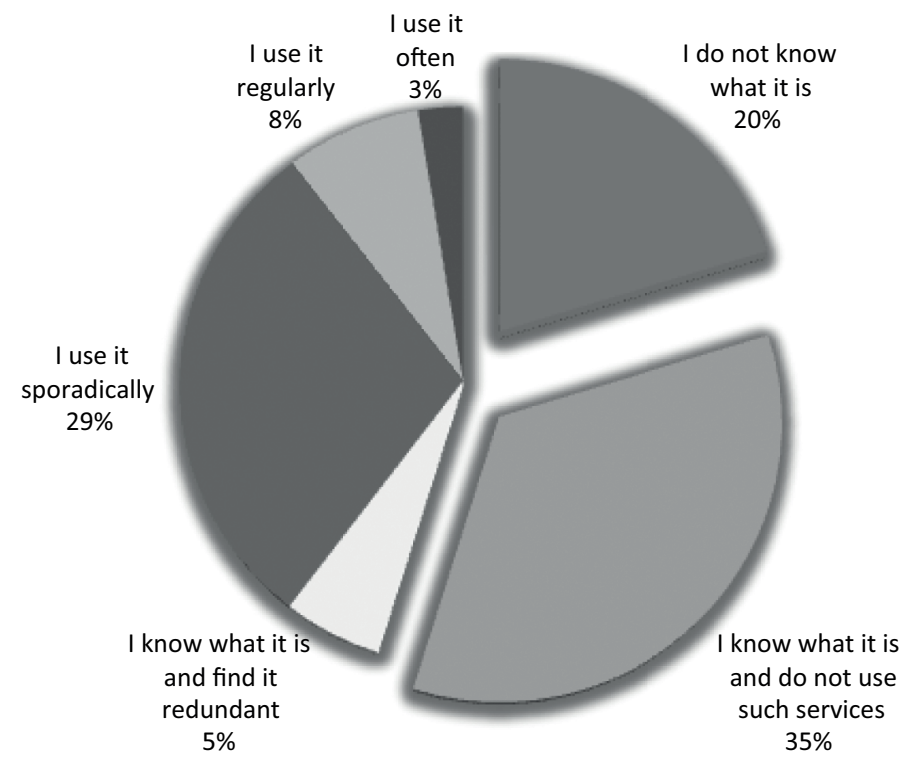

Figure 3. The respondents' attitude towards e-administration

Source: author's own work.

It transpired that overall $60 \%$ of the respondents do not avail themselves of e-administration. Gender did not prove to be a determining factor (the chi-square value $=0.933$ with the critical value $=31.41$ and alpha level $=0.05$ ). The statistically significant differences occurred when two groups of the respondents were juxtaposed, to wit, the working ones and the ones running businesses (chi-square $=66.709$ with the critical value $=31.41$ and with alpha level $=0.05)$. The coefficient for the persons making use of e-administration in the first of the two distinguished groups was $44 \%$, whereas in the other $-66 \%$. What proved to be equally interesting is another juxtaposition in the group of persons in education, which were divided into two distinct categories: people in education and people 
both working and being in education at the same time. These respondents differed from one another in a statistically significant way with respect to the use of e-administration (chi-square $=62.178$ with the critical value $=31.41$ and alpha level $=0.05$ ). It proved that the difference between the said two groups amounted to 24 percentage points.

For the purpose of the present study, the author thereof assumed three indicators. The first of them is the attitude towards BIP. As could be expected in the light of previous declarations, over $61 \%$ admitted that they do not make use of this service. Nearly as much as $29 \%$ stated that they are unaware of it. This value is rather high, especially given the fact that the logo of BIP or the link to its Internet site can be found on Internet sites of each office, public institution of higher education as well as of each hospital, political party, etc. The details related to popularity of BIP are represented in Figure 4.

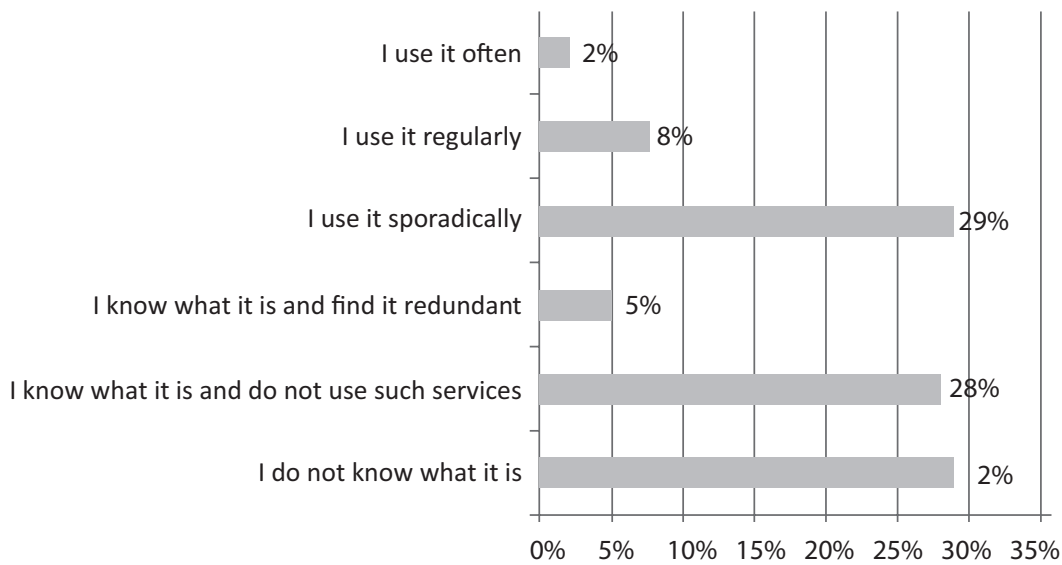

Figure 4. The respondents' attitude towards BIP

Source: author's own work.

Those results are rather surprising. After all, in 2016, there had already passed 15 years from the moment of BIP having started to operate. The respondents admitting that they make use of BIP were asked to answer the question of which services they take advantage of. They were supposed to indicate at most three services. The decisive majority, that is, $90 \%$, admitted that they check opening hours of offices as well as the ways of contacting them. About $25 \%$ of them indicated that they check the mode of doing some errands. Slightly more than $25 \%$ chose reviewing job offers in the units running a given bulletin. It is to be noted that the respondents 
in the majority of cases indicated the services located at the first of the five levels of the development of e-administration services, to wit, at the information level.

Whereas the results in previous categories were poor, the ones pertaining to the service labelled as e-PUAP are even worse. As much as $41 \%$ said that they are unaware of such a service. $34.4 \%$ said that know about it but never make use of it. Nearly $5 \%$ thought it redundant. It is only $0.9 \%$ that admitted they use it rather often. The details are presented in Figure 5. As expected, the highest coefficient of the persons using (with any frequency whatsoever) e-PUAP was to be found in the group of persons running business. It is apparently related to the fact that some issues can be arranged only electronically.

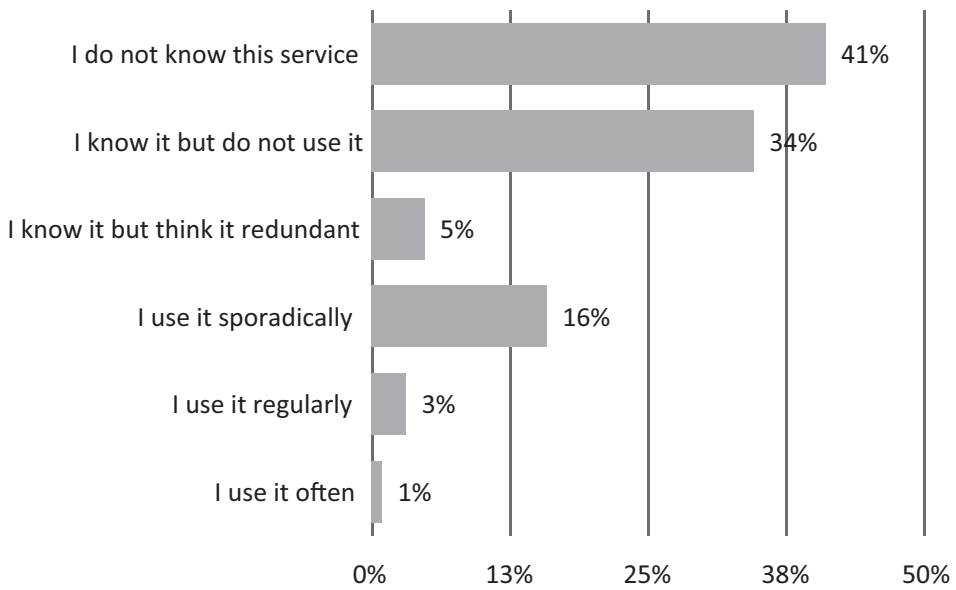

Figure 5. The respondents' attitude towards e-PUAP

Source: author's own work.

The last indicator assumed for the purpose of the present study was about making use of e-declarations. In 2016, about 6 million Pit-37 tax declarations were submitted; and therefore, the expectations towards this service were quite high. It transpired that it is also in this category that over $60 \%$ of the respondents do not use this service, and only as much as $32.9 \%$ do. However, judging the results in this category globally is erroneous since not all the respondents have tax liability. For instance, it is persons in education that are not tax liable, while the persons receiving an allowance from ZUS [Social Insurance Institution], which includes pensioners and disability pensioners, the accounts with whom 
may be settled by this institution itself. Yet, when we take into consideration only those respondents that are occupationally active, the results get changed - the percentage of the persons making use of e-declarations amounts to $45 \%$. We are going to end up with still other indicators when we analyze the group of the persons running businesses. In this group, the percentage of the persons submitting e-declarations amounts to $61.5 \%$.

As the presented data indicates, the surveyed inhabitants of KuyavianPomeranian Voivodeship do not sufficiently exploit the services provided electronically. What are the causes of this state of affairs? The respondents were allowed to indicate at most three answers to the question of what, in their opinions, raises most serious doubts and controversies or uneasiness when it comes to broadly understood e-administration. Only $1.8 \%$ of the respondents did not provide any answer. What raises the greatest doubts among the respondents is the level of safety of the data transferred online $-46.8 \%$ of all the answers. The second most popular answer (with the indicator being 32.1\%) was the lack of abilities on the part of the citizens. The third most popular choice (with the indicator reaching the value of 22.5\%) was the lack of information campaigns related to the options of making use of e-services. What was indicated least were hardware requirements (5.9\%) and the lack of mobile applications related to e-administration (6.3\%).

In the present author's opinion, the good symptom is that the respondents pay attention to security. Yet, care therefor must be cherished both on the part of users and service-providers. What is telling is the fact that the second position was occupied by the lack of abilities on the part of the citizens - this in turn constitutes a major challenge to the education sector. Perhaps the curriculum should be changed? This level of digital ability constitutes also a challenge to the Ministry of Digital Affairs, self-governments and non-governmental organizations - one should focus on educating citizens. There are sometimes dozens, nay, even hundreds of millions of zlotys spent on information system and no amounts are allocated to education actions. The option that was rated as second is strictly connected with the option that occupied the third position. The lack of information to the citizens - it is most conspicuously noticeable in the case of the service labelled as ePUAP, which was unknown to $41 \%$ of the respondents. That is a major failure, especially when we confront this indicator with the spending on that system. According to the author of this paper, one should take heed of two more issues, that is, of the low level of user-friendliness 
of information systems and clerks' attitudes towards e-administration. These possibilities were considered by the respondents but eventually, they were located at still more distant positions.

To summarize the results of the survey directed at the inhabitants of Kuyavian-Pomeranian Voivodeship, the said results should be confronted with the data related to whole Poland. According to the latter, in $2016,30.2 \%$ of the inhabitants of Poland declared that they had made use of e-administration in the preceding twelve months. The present author's research indicates a slightly higher level of making use of e-administration. However, the scope of the survey was not so limited in time in this respect. Instead, the presented results of the research depict the inhabitants of Kuyavian-Pomeranian Voivodeship as not interested in e-services, or even as not being aware of them at all. However, such an opinion would be rather harmful for them, which is evidenced by their declarations pertaining to shopping online. Only as little as $4.7 \%$ stated that they are unaware of such a service and merely $15.5 \%$ declared that they are conscious of e-shopping but not make use thereof. Overall, it is $79.5 \%$ of the respondents that does online shopping with a variable frequency. It is such a high coefficient that one may venture a claim that the respondents make use of those services that they trust, e.g., the ones relating to data safety, making payments, etc. They choose online services if these bring them tangible benefits, e.g., lower price or speedier delivery. Another contributing factor is user-friendliness, or the ease with which one can operate information systems. It must be conceded that electronic trading is normally a commercial solution. The owners, bearing costs, usually make considerable effort to have a return on investment, the investment being spending on computerization, and to ultimately generate profits.

\section{CONCLUSION}

The answer to the question of whether and to what extent Poles are ready for digital government is complex and far from obvious. Once one attempts to provide such a definite answer, one must undoubtedly consider the parameters of generation group, level of education and professional status. Despite the influence of so many determinants, one may formulate the answer that the inhabitants of Poland are sufficiently prepared for functioning within 
digital government; yet, the process of making Poland digital government has barely started. The above-mentioned level of preparation is unsatisfactory. The said level will be higher if the suggested solutions prove to be user-friendly, stable, safe and actually functioning 24/7. These are the most important postulates with respect to technology. What still remains is the administrative-legislative area, e.g., a part of services enumerated on ePUAP platform is unavailable in some offices. The decision-makers responsible for the choice of technological solutions are obligated to diagnose and analyze the needs and opinions of users. Making judgments based merely on the data collected by the Polish Central Statistical Office is insufficient. Especially given the fact that some part of the data is transferred by the offices which take interest in portraying themselves in the best possible light. Another postulate is to run information-educational campaigns in which the emphasis would be put not only on rights and duties of the user of a system but also on the possibilities granted by ICT technologies and contributing to the development of the civil society, e.g., voting online on the participatory budget. The last but not least issue is uniformizing the official procedures across Poland. Digital government will not be a mere fantasy in Poland if the attitude towards the process of digitization of the society changes.

\section{REFERENCES:}

Bangemann, M. (1997). The Information Society - The EU Framework. Business Strategy Review, 8(4), 13-16. DOI: 10.1111/1467-8616.00043.

Batorski, D. (2015). Technologie i media w domach i w życiu Polaków. In: J. Czapiński, \& T. Panek (eds.), Diagnoza społeczna. Warunki i jakość życia Polaków. Raport (pp. 373-395). Warszawa: Rada Monitoringu Społecznego.

Boniecki, D. et al. (2016). Digital Poland: Capturing the Opportunity to Join Leading Global Economies. Warszawa: McKinsey \& Company, Forbes Polska.

Główny Urząd Statystyczny (2012). Wyniki Narodowego Spisu Ludności i Mieszkań. Podstawowe informacje o sytuacji demograficzno-społecznej ludności Polski oraz zasobach mieszkaniowych. Warszawa.

Główny Urząd Statystyczny (2018). Bank Danych Lokalnych. Wynagrodzenia $i$ świadczenia społeczne. Retrieved from: https://bdl.stat.gov.pl/BDL/dane/podgrup/ tablica.

Komitet Badań Naukowych (2000). Cele i kierunki rozwoju społeczeństwa informacyjnego $w$ Polsce. Retrieved from: http://kbn.icm.edu.pl/cele/cele.html.

Ministerstwo Łączności (2001). ePolska. Plan działań na rzecz rozwoju społeczeństwa informacyjnego w Polsce na lata 2001-2006. Warszawa. 
Ministerstwo Nauki i Informatyzacji (2004). Proponowane kierunki rozwoju społeczeństwa informacyjnego w Polsce do 2020 roku. Retrieved from: http://www.rgnisw. nauka.gov.pl/g2/oryginal/2013_05/d41f5254503ef71e393b72dabaa78900.pdf.

Ministry of Finance (2018). Retrieved from: https://www.finanse.mf.gov.pl/systemyinformatyczne/e-deklaracje/statystyka.

Naczelna Izba Kontroli (2016). Świadczenie usług publicznych w formie elektronicznej na przykładzie wybranych jednostek samorzadu terytorialnego. Retrieved from: https:// www.nik.gov.pl/plik/id,10420,vp,12749.pdf. 